Rawat Kanupriya, Pujszo Ryszard, Wojdat Marta, Zając Magdalena. A comparative analysis of the sense of optimism and life satisfaction among judo and brasilian jiu jitsu fighters. Journal of Education, Health and Sport. 2022;12(2):34-47. eISSN 2391-8306. DOI http://dx.doi.org/10.12775/JEHS.2022.12.02.004

https://apcz.umk.pl/JEHS/article/view/JEHS.2022.12.02.004

https://zenodo.org/record/5956486

The journal has had 40 points in Ministry of Education and Science of Poland parametric evaluation. Annex to the announcement of the Minister of Education and Science of December 21, 2021. No. 32343. Has a Journal's Unique Identifier: 201159. Scientific disciplines assigned: Physical Culture Sciences (Field of Medical sciences and health sciences); Health Sciences (Field of Medical Sciences and Health Sciences).

Punkty Ministerialne z 2019 - aktualny rok 40 punktów. Zalaccznik do komunikatu Ministra Edukacji i Nauki z dnia 21 grudnia 2021 r. Lp. 32343. Posiada Unikatowy Identyfikator Czasopisma: 201159. Przypisane dyscypliny naukowe: Nauki o kulturze fizycznej (Dziedzina nauk medycznych i nauk o zdrowiu); Nauki o zdrowiu (Dziedzina nauk medycznych i nauk o zdrowiu).

(1) The Authors 2022;

This article is published with open access at Licensee Open Journal Systems of Nicolaus Copernicus University in Torun, Poland

Open Access. This article is distributed under the terms of the Creative Commons Attribution Noncommercial License which permits any noncommercial use, distribution, and reproduction in any medium, provided the original author (s) and source are credited. This is an open access article licensed under the terms of the Creative Commons Attribution Non commercial license Share alike.

tion and reproduction in any medium, provided the work is properly cited.

The athors declare that there is no conflict of interests regarding the publiettion of this paper.

Received: 25.01.2022. Revised: 25.01.2022. Accepted: 03.02.2022.

\title{
A comparative analysis of the sense of optimism and life satisfaction among judo and
} brasilian jiu jitsu fighters

Rawat Kanupriya ${ }^{1}$, Pujszo Ryszard ${ }^{2}$, Wojdat Marta ${ }^{3}$, Zając Magdalena ${ }^{4}$

${ }^{1}$ Department of Psychology, Kazimierz Wielki University, Bydgoszcz, Poland

${ }^{2}$ Institute of Sport and Physical Culture, University of Economy, Bydgoszcz, Poland

${ }^{3}$ Student Scientific Circle "WyKoNa", Kazimierz Wielki University, Bydgoszcz, Poland

${ }^{4}$ Department of Pedagogy, Kazimierz Wielki University, Bydgoszcz, Poland

Correspondence: Kanupriya Rawat

kanupriyarawat96@gmail.com

Kazimierz Wielki University

Department of Psychology

Leopolda Staffa 1,

85-867, Bydgoszcz, Poland

The article is a development of unpublished materials presented during the conference "2nd

HMA World Congress, 14-17 June 2018, Gdańsk" 


\section{Abstract \\ Background and Study Aim}

The main aim of the study was to determine the level of optimism and life satisfaction among men of different ages who professionally or recreationally practice judo and Brazilian jiu-jitsu.

\section{Material and Methods}

The study involved 43 judo athletes, 43 Brazilian jiu-jitsu athletes (BJJ) and 42 persons in a control group (homogenously selected in terms of sex and age). The study used the SWLS scale to determine the satisfaction with life and the LOT-R test to determine the level of optimism. Descriptive parametric statistics were presented in order to show the analysed variables. Due to the number of subjects in groups, nonparametric statistics were used in the analysis - to analyse the differences, the Anova Kruskal-Wallis test; to analyse correlations between variables, the agglomerations method using Euclidean distances (single bond in space). In the analysis of the magnitude of the influence of variables on life satisfaction and optimism, parameter $\beta$ was used - the significance of the parameter ( $p$ ) was based on Wald's statistics.

\section{Results}

Analysis of intergroup differences for the judo, BJJ, and control groups revealed significant differences in education, social status, professional work, and health condition.

The compared psychological variables - quality of life and life orientation in terms of standardised results did not reveal significant differences; however, the dichotomous division of the quality of life allowed indicating the distinctness of the compared groups.

The analysis of multiple comparisons revealed that the differences only concerned the characteristics of the judo and the control groups, while the BJJ and the judo groups significantly differed in the quality and the length of their sports careers. Systems of characteristic features to explain the quality of life and life orientation were also searched for - the agglomerations method allowed indicating the distinctness of the BJJ and the judo groups in terms of the length of their sports careers.

Based on the conducted logistic regression analysis, the likelihood of high or low quality of life and of life orientation and optimism in both groups of athletes has been identified, and differences consistent with previous observations have been indicated.

\section{Conclusions}

The subjects involved in combat sports significantly differ from those who do not practice sports in terms of education, social status, work situation and health assessment. The presence of high or low life satisfaction differentiates the compared groups.

Key words: Judo, Brazilian jiu-jitsu, health status, sports career, SWLS, LOT-R 


\section{Introduction}

The sense of optimism and satisfaction with life represent a very important aspect of life of an individual and of the society as a whole. Among others, it is these factors that the quality of social contacts, which affect a person in a secondary way, depends on. Optimism and satisfaction with life are values that can be a driving force to take on tasks and to deal with difficulties. This means that certain aspirations, plans, or activities of a physical, mental, social or spiritual nature are taken up due to the values playing the central role in the individual hierarchy of values [1]. Satisfaction with life is one of the elements of subjective well-being, which also consists of positive feelings and a lack of negative feelings. Its assessment results from a comparison of one's personal situation with the standards set on a basis of one's own set of criteria. It is a conscious, cognitive process of global assessment of life. Thus, if the result of the comparison is satisfactory, it brings a feeling of satisfaction $[2,3]$. It is preconditioned by many factors operating in different time perspectives, for example: personality traits, life events from several years before and the current mood [4]. To describe this construct, literature interchangeably applies the terms "quality of life" or "satisfaction with life". Satisfaction, as a sense of contentment, usually represents a resultant between expectations and the achieved result. The sense of satisfaction will be low when there is too much discrepancy between expectations and effects [5]. A similar correlation concerns declarative optimism. Scheier and Carver [4] defined the way of perceiving the world consisting in expecting more positive experiences as dispositional optimism. According to the authors, it is a permanent personality trait rather than a variable dependent on the current situation [4]. The sense of pride and complacency is not a sign of disorder, but self-labelling that is essential for proper development and without which a person is unable to function normally. The term narcissism, i.e. falling in love with oneself, loving oneself, is also associated with this phenomenon; however, it has negative connotations in everyday life. Basińska et al. [8] proved that the difference in narcissism between professionals and nonsports people is a stereotype and that only women practising combat sports have a higher level of narcissistic traits. It is, therefore, important to search for resources that can form a basis for development. Research shows that optimism is a key personal resource that affects physical state and well-being and promotes succeeding in life and protecting oneself from stressful situations [8]. Motivation, the type of undertaken actions and perseverance in their realization depend on the level of optimism. The development of this trait is influenced by biological factors - heredity and temperament, and by environmental factors - influence of parents, 
teachers and early life experience [6,7,8]. The level of optimism, as well as the level of satisfaction with life, has a significant impact on human life. Taking into account external factors, including the environmental ones, attention is drawn to the positive, even healing, influence of sport on perceiving life events, and thus on the feeling of satisfaction with life and optimism.

Sport as a supporting factor has been a subject of many studies, hence the choice of judo athletes and men practising BJJ as representatives of research groups in which a sense of satisfaction with life and declarative optimism were measured. Sports training acts as a biological stimulator of organs. Adequately chosen, it allows maintaining the proper condition of the musculoskeletal-ligament apparatus [9]. In addition to physical health benefits from the progress, there are also mental benefits - a feeling resulting from a well-accomplished task, increased optimism and satisfaction. A person who realises himself in one field also has a chance to realise himself in others [10]. Research conducted to date has shown that satisfaction with physical activity or sport is one of the determinants of the quality of life of people involved in active or occasional sports participation [10]. Researchers also pay attention to the fact that the programmes implemented to promote active lifestyles bring unexpected results, such as a change of mood [11]. This can be compared to the so-called tip of an iceberg effect, where the high level of vigour is accompanied by low levels of anxiety, depression, hostility, which in turn brings better well-being and better self-esteem [12]. The sport-related sense of life, as an important motive of human behaviour, promotes the formation of a personality rich in an ability to establish appropriate interpersonal relationships and to increase the support network, which translates into ease in facing everyday tasks and the generally perceived improvement in the quality of life [13]. Therefore, it is important to measure the influence of sport and the principles which athletes follow on the sense of satisfaction with life and on the feeling of optimism. Knowledge of this impact may allow the implementation of a series of corrective and rehabilitative actions which will help to increase the sense of satisfaction with life and perceived optimism. It should be noted that research in the field of sport psychology covers many aspects concerning the relationship between "psyche" and the body's physiological capacity, resistance to stress, attention span, sport results, and many others. These studies also carried out among athletes practising combat sports, e.g. judo, bring ever newer solutions to improve coaches' work $[14,15,16]$. 
Being part of the above scientific trend, the authors have conducted a study of the level of optimism and satisfaction with life among men of different ages who professionally or recreationally practice judo and Brazilian jiu-jitsu.

\section{Material and methods}

The study involved 43 judo athletes, 43 Brazilian jiu-jitsu athletes (BJJ) and 42 persons in the control group (homogenously chosen in terms of sex and age). The survey used the SWLS scale to determine the satisfaction with life and the LOT-R test to determine the level of optimism. The tests were obtained from the Department of Psychological Tests at Kazimierz Wielki University in Bydgoszcz.

The survey was accompanied by sociodemographic questions assessed in an ascending order: education (values 1-5), self-assessment of one's social status (values 1-4), self-assessment of one's professional work (values 1-4), self-assessment of one's life situation (values 1-4), self-assessment of health (values of 1-4) and questions about the quality of sports career (1-4) and the total length of sports career expressed in years. A total of 128 persons were tested.

Parametric descriptive statistics have been presented to show the analysed variables. Due to the number of subjects in groups, nonparametric statistics were used in the analysis to analyse the differences, the Anova Kruskal-Wallis test; to analyse correlations between variables, the agglomerations method using Euclidean distances (single bond in space). In the analysis of the magnitude of the influence of variables on satisfaction with life and optimism, parameter $\beta$ was used - the significance of the parameter (p) was based on Wald's statistics. Mathematical Euclidean distances are visualized in graphs. All test values which meet the condition of $\mathrm{p}<0.05$ are considered statistically significant; results meeting the condition that $0.1 \leq \mathrm{p}<0.05$ are assumed to be a statistical trend.

The analysis was conducted using the Statistica 12 package, licensed for use by Kazimierz Wielki University.

The results are presented in Tables $1-3$ and in Figures 1-2.

\section{Results}

First, the sociodemographic data for the examined groups and intragroup differences were defined. 
Table 1. Sociodemographic data of subjects in all groups (judo, Brazilian jiu-jitsu, control group)

\begin{tabular}{|c|c|c|c|c|}
\hline & & & Kruskal-Wallis Anova & $\mathrm{p}$ \\
\hline & & (mean rank) & Rank (H) & \\
\hline \multirow[t]{3}{*}{ education level } & judo group & 79.1 & \multirow[t]{3}{*}{12.23684} & \multirow[t]{3}{*}{$0.0022^{*}$} \\
\hline & bjj group & 61.17 & & \\
\hline & control group & 52.95 & & \\
\hline \multirow[t]{3}{*}{ social status } & judo group & 78.71 & \multirow[t]{3}{*}{16.1367} & \multirow[t]{3}{*}{$0.0003^{*}$} \\
\hline & bjj group & 65.12 & & \\
\hline & control group & 49.32 & & \\
\hline \multirow[t]{3}{*}{ work situation } & judo group & 80.32 & \multirow[t]{3}{*}{18.2408} & \multirow[t]{3}{*}{$0.0001 *$} \\
\hline & bjj group & 64.15 & & \\
\hline & control group & 48.65 & & \\
\hline \multirow[t]{3}{*}{ health condition } & judo group & 74.38 & \multirow[t]{3}{*}{8.7004} & \multirow[t]{3}{*}{$0.0142 *$} \\
\hline & bjj group & 66.46 & & \\
\hline & control group & 52.36 & & \\
\hline \multirow[t]{3}{*}{ life situation } & judo group & 69.15 & \multirow[t]{3}{*}{2.86} & \multirow[t]{3}{*}{0.24} \\
\hline & bjj group & 67.13 & & \\
\hline & control group & 57.04 & & \\
\hline
\end{tabular}

* - statistically significant

Table 2. Demographic and sports data of the subjects in all groups (judo, Brazilian jiu-jitsu, control group)

\begin{tabular}{llllll}
\hline & $\begin{array}{l}\text { Age (years) } \\
(\mathrm{M}, \pm \mathrm{SD})\end{array}$ & $\begin{array}{l}\text { Range (years) } \\
(\min -\mathrm{max})\end{array}$ & $\begin{array}{l}\text { Sports career } \\
\text { quality (rank } \\
\text { mean })\end{array}$ & $\begin{array}{l}\text { Sports career total } \\
\text { length }(\mathrm{M}, \pm \mathrm{SD})\end{array}$ & $\begin{array}{l}\text { Range (min- } \\
\max )\end{array}$ \\
\hline Judo group & $\begin{array}{l}35.62 \\
( \pm 13.56)\end{array}$ & $(18-63)$ & 56.23 & $2.3( \pm 0.802)$ & $(1-4)$ \\
\hline Bjj group & 32.99 & $(18-57)$ & 30.77 & $1.418( \pm 0.698)$ & $(1-4)$ \\
& $( \pm 10.64)$ & & & & \\
\hline $\begin{array}{l}\text { Control } \\
\text { group }\end{array}$ & 35.125 & $(21-62.5)$ & & & \\
\hline
\end{tabular}


Table 3. SWLS and LOT-R test results for subjects in all groups (judo, Brazilian jiu-jitsu, control group)

\begin{tabular}{lllll}
\hline & $\begin{array}{l}\text { SWLS (sten) }(\mathrm{M}, \\
\pm \mathrm{SD})\end{array}$ & Range (sten) & $\begin{array}{l}\text { LOT-R (sten) } \\
(\mathrm{M}, \pm \mathrm{SD})\end{array}$ & Range (sten) \\
\hline Judo group & $6.9535(1.689)$ & $4-10$ & $7.0139(1.5348)$ & $1-10$ \\
\hline Bjj group & $6.8372(1.999)$ & $2-10$ & $7.093(1.7839)$ & $1-10$ \\
\hline Control group & $6.0000(1.951)$ & $2-10$ & $5.976(2.599)$ & $1-10$ \\
\hline
\end{tabular}

Despite the revealed statistically significant differences between the examined groups in terms of dichotomically divided satisfaction with life $(\mathrm{H}(2, \mathrm{~N}=128)=6.283535 \mathrm{p}=0.0432)$, the difference in sten distributions remained at the level of a statistical trend $(\mathrm{H}(2, \mathrm{~N}=128)$ $=4.870895 \mathrm{p}=0.0876$ ). In multiple comparisons, intragroup differences have not been found to significantly influence the demonstrated intergroup differentiation. In terms of LOT-R, statistically significant differences were not revealed.

Then, relationships between the tested variables were established in cluster analysis by means of the agglomeration method.

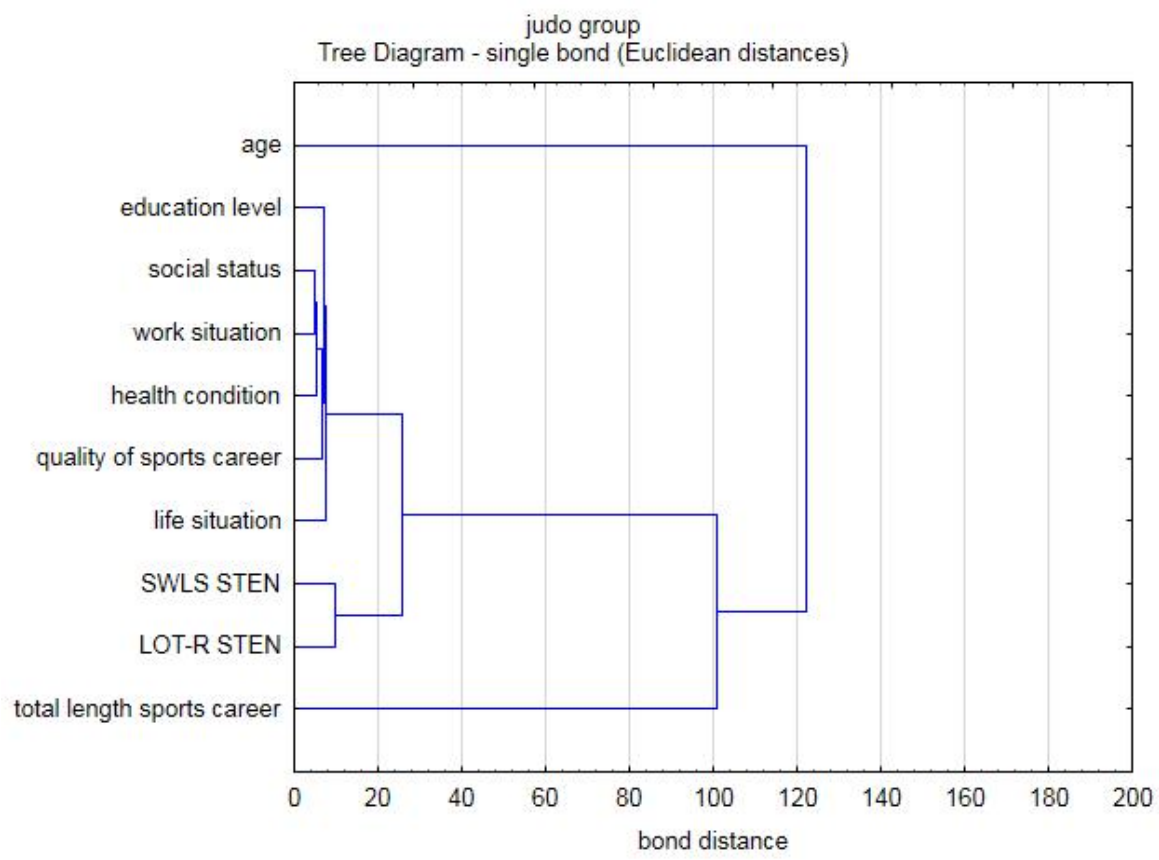

Figure 1. The course of the agglomeration chart of the judo group with Euclidean single bond 
It can be ascertained in the studied group of judo athletes that satisfaction with life (104) and optimism (106) are poorly related to the total length of the sports career, yet more strongly with the career quality $(50 ; 51)$, which is linked to sociodemographic variables to a greater extent (education (7), social status (8), work situation (12), life situation (11), and health condition (10)); the subjects' age has the weakest relationship with the analysed variables.

Analysing Euclidean single bonds of variables in the group of Brazilian jiu-jitsu athletes, it can be ascertained that satisfaction with life (21) and optimism (24) are the most strongly related to the total length of a sports career and relatively strongly with the career quality (38). Similarly to judo athletes, the weakest relationships are with the subjects' age, while sociodemographic variables (education, social status, work situation, health, and life situation) are considerably more strongly (7-14) correlated with one another than with SWLS or LOT-R (28-30).

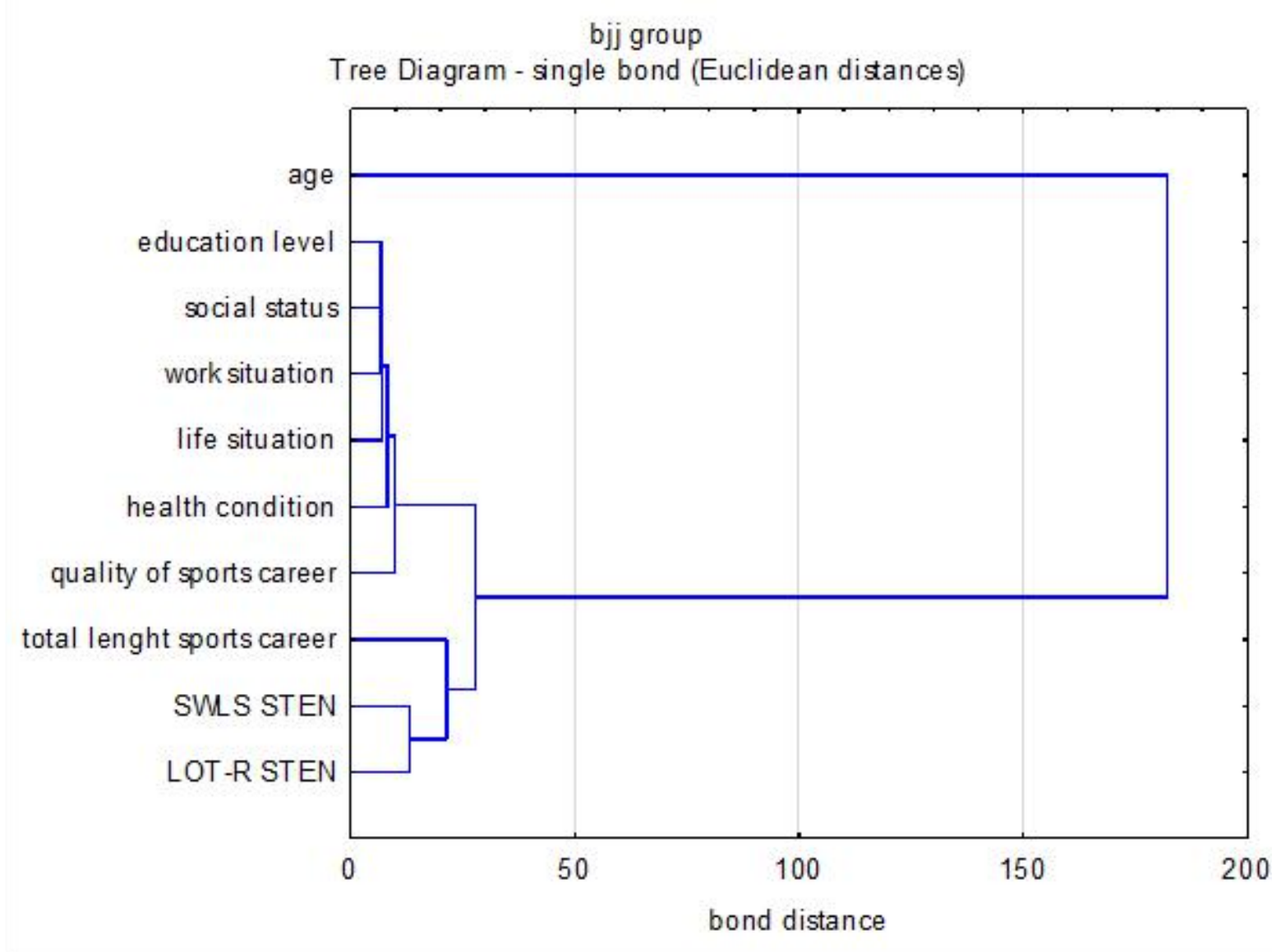

Figure 2. Course of the agglomeration chart of the Brazilian jiu-jitsu group (BJJ) with Euclidean single bond

Logistic regression analysis revealed differences in terms of satisfaction with life between judo and Brazilian jiu-jitsu athletes. In the group of judo athletes, the subjects' age, the total 
length and quality of their careers, education and health condition had vital significance for explaining high or low levels of satisfaction. It was proved that factors not included in the study (a significant absolute term) also influence satisfaction. In the group of Brazilian jiujitsu athletes, satisfaction with life was significantly influenced by the total length of career, work situation, life situation and the quality of sports career.

In further analysis, it was ascertained that younger age $(\beta=-0.0155 ; p=0.024)$, longer sports career $(\beta=0.01414, p=0.0076)$, a high health assessment $(\beta=0.2345, p=0.00001)$ are conducive to the examined judo athletes' high satisfaction with life. On the other hand, the factors that decrease satisfaction with life include higher education $(\beta=-0.2354, p=0.0087)$, average social status $(\beta=-0.2351, p=0.0002)$, high assessment of professional work $(\beta=-0.1916, p=0.04)$, average assessment of health $(\beta=-0.335, p=0.0019)$, and low quality of a sports career $(\beta=-0.2392, p=0.0231)$.

In the group Brazilian jiu-jitsu athletes, high life satisfaction is influenced by the overall length of a sports career $(\beta=0.0594, \mathrm{p}=0.0001)$, average assessment of professional work $(\beta=0.223, p=0.011)$, high assessment of life situation $(\beta=0.2486, p=0.0028)$. Factors that are not conducive to high life satisfaction include average assessment of life situation $(\beta=-0.3832, p=0.0325)$ and high assessment of the sports career $(\beta=-0.6718, p=0.0011)$.

\section{Discussion}

An athlete's social status has its origins in antiquity as the sports professionalism was already present in the era of ancient Olympic Games in Greece, which resulted in the emergence of a peculiar "athlete's cult". A sportsman's career was a very attractive path of life development (as opposed to Rome) [17]. This phenomenon is also noticeable in today's societies, especially in the poorer Afro- and Latino-American communities [18, 19, 20]. The results of research in the group of judo athletes in terms of the social status are similar to the international ones. Looking at studies conducted earlier, it can be seen that the population of the examined group of judo athletes is dominated by approximately $80 \%$ of well and very well-educated people, working in different jobs, at middle- or high-level positions and with income at the level of the national average or higher [21]. This result significantly deviates from other economic studies that report that former athletes very often fail in business and only resort to safe allocation of the accumulated funds. Few of them can count on wealth till the end of their lives [22]. 
The conducted analyses confirm the previous research reports, which testify to very good education especially among persons practising judo. It should be noted, however, that practising competitive sport also means difficulties in gaining education, risks of injuries or acquired diseases disrupting normal functioning, lack of professional work experience, sometimes lack of insurance and pension contributions, increased aggression, (post)doping stress and others [23,24,25,26,27]. Previously conducted studies had shown that the type of professional work is indicative of all the said ways of employment and does not differentiate the examined groups in a significant way. As demonstrated by previous research, in the group of Brazilian jiu-jitsu athletes, satisfaction with life is significantly influenced, among others, by professional work, which simultaneously can bring satisfaction and increase self-esteem and be an escape in the form of training. Athletes' health condition is usually presented in research results favourably for exercising persons. They are distinguished by very good health and well-being. Previous research had shown that people who were highly active in their youth easily dealt with daily chores and assessed their current health condition very well [28]. Further analysis showed that in the judo group, among others, high health assessment, which strongly correlates with the quality and the length of training, is conducive to high satisfaction with life [29, 30].

Research shows that the highest level of satisfaction is characteristic of athletes, and especially of those practising judo. Achievements that strengthen one's self-esteem are vital for the sense of satisfaction with life. Athletes also experience an increase in life satisfaction depending on the level of their achievements [31]. In judo athletes, the level of perceived optimism and satisfaction is associated with sociodemographic variables. A similar situation takes place in the analysis of the type of combat sport, which differentiates the role of the career length in explaining satisfaction with life and optimism - in persons practising judo, the length of career does not affect the quality of life. This may be associated, among others, with the so-called Bushido code [32,33], which in some respects determines judokas' way of thinking and perceiving events. Comparing the level of satisfaction with life with perceived optimism, it is worth noting that athletes, particularly those practising combat sports, including judo and Brazilian jiu-jitsu, have a significantly higher rate of satisfaction and optimism than persons from the control group. This may be related to an increase in endorphins in the body during trainings - but this hypothesis requires further verification [34, 35]. 


\section{Conclusions}

1. The examined combat sports athletes significantly differ from those who do not practise sports in education, social status, work situation and health assessment. These differences are particularly apparent in comparison of those who practise judo and inactive persons.

2. The presence of high or low life satisfaction varies between the groups - the highest level of satisfaction is characteristic of athletes, especially those practising judo.

3. In persons practising Brazilian jiu-jitsu, satisfaction with life and optimism are more strongly associated with the length and the quality of their sports careers, while in the case of persons practising judo with sociodemographic variables.

4. The type of combat sport (bjj vs. judo) differentiates the role of the career length in explaining satisfaction with life and optimism - in judo athletes the career length does not affect the quality of life.

\section{References}

1. Wnuk M, Marcinowski TJ. (2010) Rola wartości dla poczucia sensu życia oraz satysfakcji z życia studentów.The role of value for students' sense of life and satisfaction with life. Problemy Higieny i Epidemiologii 91(3): 458-462.

2. Diener, E, Emmons RA, Larson RJ et al. (2010) The Satisfaction with Life Scale. Warszawa: Pracownia Testów Psychologicznych Polskiego Towarzystwa Psychologicznego.

3. Świerżewska D. (2010) Satysfakcja z życia aktywnych i nieaktywnych osób po 60. roku życia .Satisfaction with life of active and inactive people aged over 60.. Psychologia Rozwojowa 15(2):89-99.

4. Scheier MF, Carver CS, Bridges MW. (2001) The Life Orientation Test-Revised. Warszawa: Pracownia Testów Psychologicznych Polskiego Towarzystwa Psychologicznego

5. Derbis J, Jędrek K. Poczucie (2010) Jakości życia a osobowość sportowców dyscyplin indywidualnych $\mathrm{i}$ zespołowych. A sense of the quality of life and personality of athletes of individual and team disciplines. Przegląd Psychologiczny, 5,3(1): 9-32 . 
6. Jakubowska E, Jakubowski K, Cipora E. (2010) Satysfakcja z życia chorych z cukrzycą. Satisfaction with the life among patients with diabetes. Probl. Hig. Epidemiol, 2:308-313.

7. Basińska MA, Zalewska-Rydzkowska D, Wolańska P et al. (2008) Dyspozycyjny optymizm a akceptacja choroby w grupie osób z chorobą Gravesa-Basedowa. Dispositional optimism and the acceptance of disease in a group of patients with Graves' disease. Endokrynologia Polska 59(1): 23-22.

8. Seligman MEP (2005) Prawdziwe szczęście. Psychologia pozytywna a urzeczywistnienie naszych możliwości trwałego spełnienia. True happiness. Positive psychology and realization of our possibilities of sustainable fulfillment. [Wyd]:Media Rodzina of Poznań, Poznań 1-416

9. Stach R. (2006) Optymizm. Badania nad optymizmem jako mechanizmem adaptacyjnym. Optimism. Research on optimism as an adaptive mechanism. Wydawnictwo Uniwersytetu Jagiellońskiego. Kraków.

10. Czerwiak G, Krawczyńska J. (2005) Rola sportu w akceptacji własnej niepełnosprawności osób z dysfunkcją narządu ruchu. The role of sport in accepting one's disability among people with locomotor dysfunction. Kielce Akademia Świętokrzyska, Instytut Kształcenia Medycznego.

11. Pieszak E. (2012) Aktywność fizyczna a jakość życia osób z ograniczoną sprawnością. Physical activity and the quality of life among people with limited fitness. Ecologia Humana, 2(10): 135-147.

12. Łuszczyńska A. (2011) Psychologia sportu aktywności fizycznej. Zagadnienia kliniczne. Sports psychology of physical activity. Clinical issues. Warszawa Wydawnictwo Naukowe PWN: 1-248

13. Argyle M. (2005) Przyczyny i korelaty szczęścia. Causes and correlates of happiness. In: Czapiński J. editors. Psychologia pozytywna. Nauka o szczęściu, zdrowiu, sile i cnotach człowieka. Positive psychology. The science of happiness, health, strength and virtues of man. 165-203. Warszawa: PWN.

14. Pujszo R, Skorupa H, Smaruj M et al. (2006) Koncentracja uwagi i efekt placebo w kontroli postawy ciała. Attention focus and the placebo effect in body posture control. In. Adamski-Kęty A. editors. Człowiek - jego bioelektryczna konstrukcja a percepcja muzyki: studium monograficzne. Man - his bioelectric composition and the perception of music: a monographic study. Uniwersytet Śląski 77-83. 
15. Błach W, Pujszo R, Pyskir M et al. (2005) Kontrola postawy ciała zawodniczek judo (badania pilotażowe). Body posture control among female judo athletes (a pilot study). In: Research yearbook: studies in the theory of physical education and sport, 11: 30-36.

16. Pujszo R., Błach W, Pyskir M et al. (2006) Wpływ zmiany wysokości na kontrolę postawy ciała. The influence of a change in elevation on body posture control.. Medycyna Sportowa, 1: 17-22.

17. Lenartowicz M. (2009) Specyfika zawodu sportowca i kariery sportowej. Specificity of the an athlete's profession and a sports career. Studia Humanistyczne 9: 71-83.

18. Cedro P. (2013) Społeczna rola sportu. The social role of sport. Rozprawy Społeczne, 2(7): 77-86.

19. Földesi GS. (2004) Social status and mobility of Hungarian elite athletes. The International Journal of the History of Sport 21(5): 710-726.

20. Marqusee M. (1995) Sport and stereotype: From role model to Muhammad Ali. Race end Class, 36(4): 1-29.

21. Janowska P, Wojdat M, Antkowiak M et al. (2016) Samoocena, a wybrane elementy pozycji społecznej judoków. Self-assessment and selected elements of the social position of judokas. Journal of Education, Health and Sport, 6(9): 664-673.

22. Godlewski P. (2012) Sportowiec w realiach organizacyjnych i ekonomicznych polskiego sportu wyczynowego. An athlete in the organizational and economic realities of Polish professional sport. Zeszyty Naukowe Uniwersytetu Szczecińskiego. Ekonomiczne Problemy Usług, Przedsiębiorczość szansą rozwoju regionu. Kształtowanie przedsiębiorczości, 2:75-90.

23. Kopeć A, Napierała M, Zukow W. (2016) Kontuzje i urazy w wioślarstwie. Injuries and trauma in rowing. Journal of Education, Health and Sport 6(4): 331-354.

24. Waldzińska E, Waldziński T, Kochanowicz B et al. (2013) Urazowość wśród młodych tenisistów. Injuries among young tennis players. Ann. Acad. Med. Gedan, 43: 29-44.

25. Gawlik R. (2014) Czy astma sportowców to choroba zawodowa? Is athletes' asthma an occupational disease? Alergia Astma Immunologia, 19(3): 150-155.

26. Kostyra A. (2015) Kariera dwutorowa: sportowiec-student i sportowiec-pracownik. Double path career: sportsman-student and sportsman-employee. Journal of Education, Health and Sport 5(7):345-355.

27. Batycka-Baran A, Baran W, Kuczborska I et al. (2009) Najczęstsze infekcje grzybicze u osób uprawiających sport .Common fungal infections in persons practicing sports. Medical Mycology.Mikologia, 16(4): 56-65. 
28. Marchewka A, Jungiewicz M. (2008) Aktywność fizyczna w młodości a jakość życia w starszym wieku. Physical activity in youth and the quality of life in old age. Gerontologia Polska,16(2): 127-130.

29. Leszczyńska A. (2013) Sport to zdrowie! Refleksje o aktywności fizycznej Polaków. Sport is a health! Reflections on physical activity of Poles, 45: 179-189

30. Drygas W, Jegier A. (2003) Zalecenia dotyczące aktywności ruchowej w profilaktyce chorób układu krążenia. Recommendations for physical activity in the prevention of cardiovascular diseases. Czynniki Ryzyka,(38/39):76-84.

31. Wiśniowska M, Tasiemski T, Bauerfeind J. (2012) Athletic Identity Assessment in Disabled Sitting Volleyball Players. Physiotherapy. Fizjoterapia; 20(1):10-19

32. Lipowski M, Makarowski R. (2010) Narcyzm u sportowców-prawda czy stereotyp? Narcissism in athletes - truth or stereotype? Polskie Forum Psychologiczne 15(1): 2534.

33. Pietrzak H, Cynarski WJ. (2000) Psychologia duchowej drogi sztuk walki. Psychology of the spiritual way of martial arts. Rocznik Naukowy Ido-Ruch dla Kultury, 1: 202210.

34. Włoch R. (2013) Sport kobiet w Polsce: zaproszenie do diagnozy. Women’s sport in Poland: an invitation to diagnose. Człowiek i Społeczeństwo. Uniwersytet im. Adama Mickiewicza w Poznaniu. Wydział Nauk Społecznych, 36(1):57-77

35. Dzięgiel A, Tomanek MT. (2014) Wykorzystanie marketingu przez sport w górskich imprezach biegowych. Use of marketing by sport in mountain racing events. Studia $i$ Monografie AWF we Wrocławiu, 120: 231-242 